\title{
信頼性解析技術の現状と課題
}

\section{State of the Art in Reliability Analysis Technology of Electronic Packaging}

\author{
信頼性解析技術委員会
}

\section{1.はじめに}

高密度化／薄型化が進むエレクトロニクス製品では，従 来にみられなかったさまざまな新しい信頼性問題が顕在化 している。一方, 電気自動車や太陽電池などエネルギエレ クトロニクス分野での実装信頼性が国内外で注目されてい る1)。エネルギエレクトロニクス分野では, 他の電子部品 と比較して過酷な環境にさらされることが多く, 他の製品 と比較して長寿命が要求される。このような敩しい要求に 対して, 従来の信頼性解析技術だけでは対応が非常に困難 になりつつある。

近年，欧米を中心に故障を事前に予測してリスク管理を 行う技術 (Prognostic Health Management: PHM)の研究が活 発に進められている。本誌でも，前号（2010年11月号）に て「故障を予測するための信頼性技術の最前線」という内 容で信頼性解析技術委員会から特集を企画させていただい た。システムモニタリング, 熱設計, シミュレーション技 術, 加速試験および絶縁信頼性の現状と課題について, 各 分野での最前線の研究者による詳細な解説が行われている のでまずはそちらを参照されたい。

本稿では, 特集の内容を踏まえ信頼性解析技術の現状と 課題について, 主に構造信頼性の観点から解説する。近 年, 部品の薄型化・高密度化が進むことによりさまざまな 構造信頼性の課題が顕在化している。特に，これまではん だ接合部の熱疲労が実装信頼性における主要な課題の 1 つ であったが，それ以外にも樹脂の変形・破壊，半導体部品 におけるLow-k材の損傷, めっき配線の破壊, エレクトロ マイグレーションなど, さまざまな破壊モードが発生して いる。多種多様な破壊モードであるが，これらはいずれも 実装構造やプロセスの不均一性に関連しているといえる。 そこで, 本稿では実装構造の不均一性に着目しつつ構造信 頼性解析技術の現状と課題について述べる。

\section{2. 微細はんだ接合部の変形と破壊}

はんだ接合部のサイズは数十マイクロメートルのオー
ダーに達しており，材料の微視組織とほぼ同等の大きさと なっている。これまで，はんだ接合部の構造信頼性（熱サ イクル疲労，衝撃など）では，材料を均質であると仮定し た連続体力学をべースとして評価が行われてきた。しかし， 各結晶の力学特性が顕著となるスケールでは，これらを考 慮した評価法の確立が不可欠となる。はんだ材料に用いら れる錫は，しばしば顕著な結晶異方性を示す2)。このため, 単結晶もしくは数個の結晶で構成されるはんだ接合部では, 異方性の影響を明らかにしておくことが寿命評価の高度化 において不可欠となる。単軸引張りでは結晶異方性の影響 が顕著となるが，実装接合部のように多軸応力状態におけ る影響は試験の困難さも相まって不明な点が多い。熱サイ クル疲労では，しばしばManson-Coffin則が経験則として 用いられるが，接合部のサイズが結晶サイズと同程度の微 細バンプでは標準試験から得られた特性とは異なる場合が あるため, 微細試験片などを用いたデー夕の拡充が必要と なる。

実装プロセスのばらつきに起因した接合部形状の不均一 性は，高密度化／微細化が進むにつれて顕著となっている。 チップ抵抗におけるはんだ接続では，実装時のチップ側面 の濡れ性によって形状が大きく変化する。このとき，形状 によって温度サイクルによるき裂進展経路が変化する（破 壊モードが変化する）ことが知られている。加えて両端に 接合部を有するチップ部品では，接続のアンバランスに起 因した形状の非対称性が熱サイクル寿命に大きく影響する3)。

また，微細化に伴い接合部におけるエレクトロマイグ レーションも重要な破壊機構となっている4 ${ }^{4)}$ 。エレクトロ マイグレーションは，微細 LSI 配線の主要な破壊機構の 1 つとして知られている。微細化により電流密度が増大する ことで，はんだ接合部でも致命的な破壊をもたらす。抑制 策としては，局所的な電流密度集中の緩和が有効である が，制約の㛜しい実装部品ではその対策が難しい。

\section{3. 樹脂材料の変形之破壊}

実装構造では，樹脂材料がさまざまな箇所で用いられて 
いる。基板や成形部品をはじめとして, 封止材料, アン ダーフィル材料, 導電性接合材料など適用箇所は多岐にわ たる。樹脂材料は, 一般的にセラミックスや金属材料に比 べて弾性率が低いため, これまで応力発生の要因とはなり にくかったが, 近年の薄型化に伴う部品の極端な剛性低下 により, 樹脂の変形挙動が無視できない状況になりつつあ $3^{5)}$ 。樹脂の機械的な特徵は, 大別すると (i) 時間依存型の 非線形変形特性（粘弾性・クリープ）, (ii) 硬化プロセスに おける体積変化がある。

例えば，アンダーフィル材は顕著な粘弾性特性を示すこ とが知られており, 実装部品の熱サイクル変形時の挙動に 大きく影響することが知られている。池田らによれば，ヤ ング率だけでなくポアソン比についても顕著な粘弾性挙動 を示すことが確認されており, 実装構造に非常に複雑な応 力変化をもたらす6)。

樹脂材料は, 硬化プロセスにおいて体積が大きく変化す るため, それに起因した変形（反り変形）がしばしば高密 度実装製品では致命的となる場合がある。樹脂の硬化挙動 は, 流動挙動に強く依存するため単一の樹脂材料であって も硬化収縮挙動に不均一性が生じる7)。薄型化する部品で は, このようなプロセスの不均一性に起因した変形が非常 に大きくなる。

また, 樹脂材料は一般に線膨張係数が高いため薄型化し た半導体部品では反り変形の要因となりやすい。部品や基 板の反り変形は, はんだ接合部の過度なミスマッチをもた らすため，意図しない寿命低下をまねく。

\section{4. 界面破壊}

変形のミスマッチにより高い応力が発生する界面は, 複 雑な実装構造においても破壊の起点となりやすい。一般に, 界面強度は界面が完全に接合されていることを前提として 評価される。近年は, 界面破壊力学によるじん性評価や端 部の特異応力場を考慮した破壊力学的な手法も提案されて いる。しかし, 界面領域のサイズが小さくなっていくとと もに, 前提条件である完全接合状態を満足しないケースが ある。金属薄膜のように, スパッ夕や蒸着による製膜では ほぼ完全に接合している場合が多いが，樹脂接着の場合に は局所的には不完全接合状態となる。このため, 不完全構 造を考慮した界面強度評価手法の開発が求められている ${ }^{8)}$ 。

半導体部品では, Low-k材料の適用が進んでいる。Low$\mathrm{k}$ 材の機械的強度は他の材料に比べても低強度かつ低じん 性であるため, 破壊の起点となりやすい9)。これまで, 部 品と基板の間の変形のミスマッチを吸収してきたはんだ接 $\mathrm{m}$ 合部に抏いて, 鉛フリー化によるはんだ材の高強度化, アンダーフィル材の採用および厳しい変形拘束が原因と なって周囲に高い応力が発生している。結果として, はん だ接合部でなく部品内部の Low-k材が破損してしまい故障 に至るケースも少なくない。

\section{5. クリープ破壊}

はんだ材は一般に融点が低いため, 使用環境で容易にク リープが発生する。温度サイクル試験では, 熱疲労が主要 な破壊機構でありクリープ特性は温度保持時の応力緩和挙 動としてひずみの発生挙動に影響する。しかし，長期信頼 性を考慮する場合, クリープ変形によって生じる損傷（ク リープ破壊）が支配的な要因となる場合がある。クリープ 破壊は, 一般に低応力かつ高温環境で発生するが, プラン 卜など高温かつ長期寿命が要求されるシステムにおいては 主要な損傷機構の1つである。エネルギエレクトロニクス のように厳しい環境で長寿命が要求されるような機器に対 して, クリープ破壊も可能性のある破壊機構として検討す る必要がある。しかし, 現状の電子部品の信頼性評価にお いてクリープ破壊はあまり検討されていない。これは，変 形のミスマッチにより発生する応力が大きく, 熱疲労が主 要因であることに起因していると推定されるが，今後のエ ネルギエレクトロニクスの長寿命化においては懸念される 破壊機構の 1 つである。

\section{6. 複合負荷環境}

電子部品は, 実環境ではさまざまな環境にさらされるた め, 実際には複合環境での信頼性が重要となる。従来の実 装構造に比べ, 高密度化が進む近年の実装構造では, 複合 環境の影響が顕著になりつつある。複数の破壊モードの相 互作用下で破壊が進行するため, 破壊機構の把握が極めて 困難である。複合負荷環境には, 振動と熱疲労のように同 時に複数の負荷が課される場合と順番に負荷が作用する シーケンシャルな複合負荷の場合が考えられるが，それぞ れ異なる破壊機構となる可能性があるため整理して考察す る必要がある。

例えば，鉛フリーめっきにおける重要な信頼性問題の 1 つである錫ウィスカの発生／成長挙動は環境条件に強く依 存することが知られている。米国の The Government Electronics Information Technology Association (GEIA)の錫ウィ スカ抑制ガイドラインでは複数環境(Multiple Environmental Conditions) による成長の加速が懸念されている。しか し， IECのウィスカ試験規格である IEC60068-82-2やJEITA 規格ET-7410では，複合環境での影響については言及され ていない10)。日本では, 近年錫ウィスカに関する研究は下 火になった感があるが, 欧米では継続した研究が行われて いる。複合環境下の試験データは, 錫ウィスカだけでなく 実装信頼性として重要であり, 継続的なデー夕の蓄積が望 ましい。

\section{7. おわりに}

実装構造に関連する信頼性問題の現状と課題について解 説した。構造, 材料, プロセス, 環境の不均一性が実装信 
頼性における主要因となりつつある。このような複雑系に おける信頼性を評価するためには，個々の要素技術の高度 化はむちろんであるが新しいアプローチの開発が期待され る。

また，不均一な実装構造に対して有効な解析手段として シミュレーション技術はますます重要な役割を担うと考え られる。近年は, 前述の特集にも述べられているような破 壊プロセスのシミュレーションやリフローシミュレーショ ン, 樹脂の流動解析および電気/熱/構造シミュレーショ ンが可能になりつつある。今後は,これらのッールを駆使 した新しい信頼性管理技術の確立が求められている。

一方, シミュレーションにおいては近年検証(Verification) と妥当性確認(Validation)の重要性が指摘されている。米国 機械学会においては，シミュレーションのためのガイドラ インが発行されており, 正しいモデルで正確に評価するこ との重要性が高まりつつある11)。近年は, シミュレーショ ンの妥当性確認にも有効な検査・計測技術が開発されてい る。デジタル画像相関法(Digital Image Correlation: DIC)に よる表面の変形評価 ${ }^{12)}$, X 線やラマン顕微鏡 ${ }^{13)}$ による応力 評価は, シミュレーションの妥当性を確認するうえで重要 な技術になりつつある。また, 放射光 X 線 CT 装置を用い た実装内部の破壊挙動の可視化技術なども報告されてい る ${ }^{14)}$ 。内部のき裂進展挙動の可視化は破壊プロセスシミュ レーションの妥当性確認に有効な手段となりうる。シミュ レーションと計測技術の融合による高度な信頼性解析技術 の確立が期待される。

文責：涉谷忠弘／横浜国立大学

(2010.11.17-受理)

\section{文献}

1）信頼性解析技術委員会：“3次元実装技術と環境対応型自動 車のパワーデバイス実装における信頼性の課題, ”エレクト ロニクス実装学会誌，Vol. 12, No. 1, pp. 19-22, 2009

2) 苅谷義治：“微小体積における鉛フリーはんだの力学的特 徵, ”エレクトロニクス実装学会誌, Vol. 11, No. 5, pp. 368374,2008

3）高木寛二, 于 強, 涉谷忠弘, 宮内裕樹, 野呂幸弘： “チップ部品におけるはんだ接合部の信頼性設計手法に関 する研究〜き裂進展モードの解明とはんだ接合部の設計方 法〜, ”エレクトロニクス実装学会誌, Vol. 12, No. 7, pp.
636-642, 2009

4) E. C. C. Yeh, W. J. Choi, K. N. Tu, P. Elenius, and H. Balkan: "Current-Crowding-Induced Electromigration Failure in Flip Chip Solder Joints," Appl. Phys. Lett., Vol. 80, pp. 580-582, 2002

5）上田啓貴，佐々木拓也，三浦英生：“積層フリップチップ 実装構造の残留応力低減構造に関する研究, ”エレクトロ ニクス実装学会誌, Vol. 12, No. 6, pp. 519-525, 2009

6) 貫野敏史, 宍戸信之, 池田 徹, 宮崎則幸, 田中宏之, 畑 尾卓也：“デジタル画像相関法を用いたフリップチップパッ ケージ内部の非線形熱応力解析精度の改善, ”第 16 回エレ クトロニクスに打けるマイクロ接合・実装技術シンポジウ ム (Mate2010), 2010

7) R. Sone, Q. Yu, and T. Shibutani: "Deformation of Resin Material Due to Curing in the Thermal Process," Proc. of the ASME 2009 InterPACK Conference, 2009

8）松本 翼, 松崎富夫, 涉谷忠弘, 于 強：“樹脂一シリコ ンの微細不完全接合層を考慮したはく離強度評価, ”日本 機械学会論文集 A 編, Vol. 75, No. 755, pp. 839-844, 2009

9) 内堀千尋, M. Lee, X. Zhang, P. Ho, 中村友二 : “フリップ チップ実装工程における $\mathrm{Cu} / \mathrm{low}-\mathrm{k}$ 多層配線の信頼性向上技 術, ”電子情報通信学会技術研究報告, Vol. 108, No. 428, pp. 45-49, 2009

10) T. Shibutani, M. Osterman, and M. Pecht: "Standards for Tin Whisker Test Methods on Lead-Free Components," IEEE Transactions on Components and Packaging Technologies, Vol. 32, No. 1, pp. 216-219, 2009

11) ASME V\&V 10-2006 "Guide for Verification and Validation in Computational Solid Mechanics,” 2006

12）宍戸信之, 池田 徹, 宮崎則幸, 中村健太郎, 宮崎政志, 猿渡達郎：“デジタル画像相関法を用いた電子実装部の熱 ひずみ分布計測,”材料, Vol. 57, No. 1, pp. 83-89, 2008

13）伊藤 忠, 東 博純, 野田正治: “ラマン分光法による LSI の局所応力の解析, ” 豊田中央研究所 R\&Dレビュー, Vol. 29, No. 4, pp. 43-52, 1994

14）釣谷浩之, 佐山利彦, 上杉健太郎, 高柳 毅, 岡本佳之, 森 孝男: “放射光X線 CT 装置によるフリップチップ接合 部における熱疲労き裂の観察,” Mate2007, Vol. 13, pp. 303308,2007 